\title{
Does Digital Public Service Complaint Promote Accountability? A Comparative Analysis of Upik Yogyakarta and Qlue Jakarta
}

\author{
Dina Nurhidayati ${ }^{1}$
}

\begin{abstract}
Public services provided by government have been an intensively researched topic. Not much literature addresses principle of accountability in digital public service innovation. This study aims to identify the extent which accountability can be promoted in the utilization of digital public complaints services, using descriptive qualitative methods with Bovens Model accountability function approach. In the form of a comparative study to compare unit of analysis as public service innovation handling digital based complaints UPIK and Qlue. The results of study were carried out after a comparison of accountability analysis, based on indicators of digital based public service accountability functions. The findings are: First, accountability influenced by four functions,(1)Democratic control,(2)Guarantees,(3)Learning, (4)Performance. Second, different periods of leadership influence the dynamics of accountability development. In conclusion, accountability function embedded by Qlue was being able to cutdown bureaucrats efficiently, in addition to the political system, leadership commitment and dynamic user existence. The quality of the UPIK system is still below Qlue, but UPIK's accountability capacity is more consistent in fulfilling the elements to promote accountability through effective complaints handling mechanisms. Not only more modern facilities, the performance of program that have supported by models and appropriate complaints handling mechanisms also capable of promoting accountable organizations.
\end{abstract}

\section{Keywords:}

accountability; complaint service; digital service

\section{Introduction}

Complaint handling services have become a topic that has researched intensively by many researchers and other scientific article writing. However, there is not so much literature that addresses the principle of accountability in digital public service innovation based on public service. This study aims to identify the extent to which accountability can be promoted in using of digital public complaints services. This research uses descriptive qualitative research method with an analysis of accountability function theory approach according to the Bovens Model, in the form of a comparative study to compare the unit of analysis in the form of public service innovations handling digital based complaints in Yogyakarta namely Information and Complaints Handling Unit (UPIK) and in Jakarta namely Qlue. The Yogyakarta and Jakarta research locus is

\footnotetext{
${ }^{1}$ Department of Public Policy and Management, Faculty of Social and Political Sciences, Universitas Gadjah Mada Email: dina.nurhidayati@mail.ugm.ac.id
} 
interesting to be researched because the development is still concentrated in the two regions, demanding that the local government be involved in massive fulfillment of public services.

The results of the study were carried out after a comparison of the accountability analysis between two complaints services, reviewed from the perspective of the implementers and users based on indicators of digital-based public service accountability functions. Furthermore, the findings are as follows: First, accountability is influenced by four main functions, namely (1) The function of democratic control, (2) Guarantees, (3) Learning, and (4) Performance. Second, the factors of the different periods of leadership quite influenced the dynamics of the development of accountability manifested by Qlue. It was concluded that the accountability function embedded by Qlue was being able to cut down bureaucrats efficiently, in addition to the political system, commitment to leadership and dynamic user existence. Where the quality of UPIK systems is still below Qlue, but for accountability capacity UPIK is more consistent in meeting key elements to promote accountability through effective complaints handling mechanisms.

It is not only a matter of more modern means that will achieve effective results, because the performance of a program that has supported by the appropriate model and complaint handling mechanism will able to promote an accountable organization. Complaint handling services have become a topic that has been intensively studied by other scientific article writing. Because every public service problem that arises will be complained by many people and produces demands responsive to the role of the provider. The types of public services that the majority complains about are generally related to infrastructure goods and services. The active role between users and providers are the hope of successful public services. The involvement of public participation in government and development processes is emphasized by involving all stakeholders. To realize good governance in government organizations, the scope of community participation, accountability, legal rules, effectiveness, efficiency and the ability to promote justice and accountability must be met (Rotchanakitumnuai, 2013, p. 309). Organizations are accountable for providing explanations and actions that oppose some parties in the political system that have been given the authority to evaluate and evaluate public organizations (Starling, 2008, p. 169). The principle of accountability is also related to the planning of complaints involving considerations and decisions made by service managers carried out by public service managers to achieve good partnerships.

The development of accountability in Indonesia is more dominant in private sector entities than in the public sector. There is a mismatch, not only in Indonesia, between the accountability system and accountability information that also occurs in European countries between the Central Government and Local Governments (Cohen, Rossi, Caperchione, \& Brusca, 2018). In realizing its accountability, the central government and regional governments in the reform era are required to form a public organization for the resolution of public complaints. However, seen the low percentage of internet use in the field of public services besides the effectiveness being highlighted, accountability for service providers is an important question.

The locus of Yogyakarta and Jakarta became interesting to study because development was still concentrated in both regions. Bonus demographics and new economic centers demanded that the local government be involved in massive fulfillment of public services. Comparison between UPIK and Qlue is an object strategy and target in identifying dimensions of accountability. Comparative studies can examine differences 
and similarities between research variables, results and discussion of comparative studies will help compare data drawn into new conclusions. Involving the comparison of the two media into the unique power of this study, added by other literature more often discusses the principle of accountability in the service of public complaints that are not based on digital based public service innovations. Such as Pramusinto (2013), conducting research on complaint handling through the Mayor's program Greeting "Building Complaint Handling Mechanism for Effective Leadership" in Yogyakarta Wong and Welch (2004) proved the level of accountability between website openness and government accountability that differed from the title "Does E-Government Promote Accountability? A Comparative Analysis of Website Openness and Government Accountability" in Hong Kong. Ghilad (2008) conducted a study of the principle of accountability held in a public complaint service organization, namely the Ombudsman at the central level with financial policy, which became the specification of the research object, entitled "Accountability or Expectations Management? The Role of the Ombudsman in Financial Regulation". Thus, the object of UPIK Jogja and Qlue Jakarta research is one of the interesting complaint handling mechanism instruments. Because this study more discusses the principle of accountability in public complaints services based on digital public service innovation. UPIK and Qlue are digital based public service innovation models established at the local government level, especially the City of Yogyakarta and the City of Jakarta. Therefore, this paper attempts to investigate the extent to which UPIK's accountability as a complaint handling service is accessed through the website, and Qlue as a complaint handling service based on social media applications. Public accountability and that issue are important to be raised, because the culture, values, political systems that develop in the organizational environment will have an effect on achieving accountability. It also states that the habits of bureaucrats also influence decision makers in an organization (Yang, 2012, p. 255).

Based on the background described, this study identifies the dimensions of public accountability in the UPIK and Qlue implementation periods of 2014-2017, as well as user responses from the public regarding issues of public complaints, along with their sustainability. This background also raises researchers' questions, namely the extent to which UPIK and Qlue service accountability influences the public response to complaints that are complained and how the dimensions of accountability between UPIK and Qlue. To answer the research question, this writing is divided into four parts. First, it contains a review of the literature that is relevant to the subject matter of the discussion of public service accountability, especially relating to digital based public complaints services. Then the explanation of the research methodology includes the data analysis techniques used. Furthermore, the results and findings are discussed briefly. The findings are processed and an analysis of the discussion of theoretical and managerial implications is carried out. Finally, this writing results conclusions and hopes for further research.

\section{Literature Review \\ Complaint Handling Management}

Complaints are inputs that have the ability to encourage increased public policy and the media for dispute resolution (Irvine et al., 2010). The policy resolutions that are built will differ in reference to public administration theory, such as the concept of the New Public Management with different New Public Service (NPS) in the public administration model. The context of "listening" is shown in NPM, while "serving" the public in the NPS (Denhardt and Denhardt, 2007, pp. 28-29), NPS provides the 
development of NPM by emphasizing market competition based on efficient governance (Pramusinto, 2013). In the context of the New Public Service, submitting complaints is a part and package of public participation that requires the government to "listen", and then in turn it raises an increase in public policy and public service delivery (Pramusinto, 2013, p. 146). The application of the principles of innovation through NPS is a representation of the application of policy innovation. The public is seen as a whole and humanist through an approach that gives space to the public to collaborate and be oriented towards improving performance. So that good governance will be realized through an approach, one of which is innovation management.

The process that includes complaints of acquisition, transmission, analysis of handling and use of complaints information in decision making is an activity carried out in complaint management (Hammami, 2011, p. 301). There is a form of complaint handling mechanism with a proactive-reactive and centralizeddecentralized model recorded by Pramusinto (2013, p. 146). The proactive model occurs when complaints are actively sought with the aim of ensuring that customer satisfaction is achieved through certain compensation offers. It is different from the reactive model that arises because responses to complaints of user dissatisfaction expect service users to complain to providers

In contrast to decentralization, Ross and Littlefield, (2013, p. 202) explained that several complaints handling mechanisms were decentralized in functions entrusted to other functions such as the salesperson, which also doubles as the party that directly handles complaints. Simply, complaint handling is given autonomously to parties outside the internal agency, or special agencies that handle complaints in all fields, it will then be followed up to agencies related to the field that are complained and communicated, followed up to customer complaints from the agency. The reputation of an organization that was originally bad due to the failure of public services, which was then expressed as a public complaint, could turn into a good reputation if the 'good management complaint' is achieved and resolution of community complaints is resolved effectively and accountably.

\section{Digital Based Public Service Innovation}

Problems such as disparity in development due to the lack of proper policy analysis, corrupt behavior of public officials due to weak regulations, overlapping food security policy issues, issues of poverty, health and unemployment policies and low levels of public education are just a few examples of the failure of public policy in responding and resolve public problems (Sururi, 2017, p. 18). Settlement of problems that occur amid the community raises substantive public policy innovations that can provide strengthening resolution. In other words, something related to the fulfillment of customer expectations or needs, where the service is said to be qualified if it can provide products and services in accordance with customer needs and expectations (Yohanitas, 2016, p. 245). It means that good and competitive public service is a manifestation of bureaucratic reform, and is inseparable from the efforts of providers of public services to provide the rights of recipients of services.

Including entering the digital era and the demands of smart city, it becomes a challenge for the government to carry out digital transformation that produces better rules and programs and makes it easier for the public to deal with government services.

\section{Dimensions of Accountability in Public Services}

In a book written by Osborne and Gaebler (1993) entitled Reinventing Government: How the Entrepreneurial Spirit is Transforming 
The Public Sector noted that in it there was the beginning of the concept of accountability in understanding the practices carried out by public sector actors. Osborne (2010) entitled The new Public Governance? Emerging Perspective on The Theory and Practice of Public Governance explained that in line with the emphasis on accountability on reinventing government, the concept of accountability also entered as the main focus in New Public Management or often referred to as New Public Management (NPM). Thus, accountability in this regard is carried out by modern public sector organizations as a reflection of efforts to increase alignments with the public interest. Peters (2010, p. 165) reveals that accountability is a different concept of responsibility, accountability refers more to organizational relations as an entity with parties outside the organization. It is analogous that the scope of the interaction area is the focus of accountability, more macro than responsiveness. It is the requirement of an agency of that agency because public accountability has a main function according to Bovens (2007), namely providing democratic control (the role of democracy), preventing corruption and abuse of power (the role of constitutional), and increasing efficiency and effectiveness (learning role). In simple terms, accountability is a contract between the government and the bureaucratic apparatus, and between the government and the community.

So that the terminology of public sector accountability from Bovens, widely used by various mechanisms that make institutions more responsive to the public, in this study in particular is the testing of public accountability in institutions providing digital public complaints services.

\section{Methods}

This research is a qualitative study with a case study approach. Case studies are researchers' strategies in which researchers investigate carefully a program, event, activity, process, or group of individuals (Creswell, 2010). Based on the background described earlier, the problem is made so that the scope of this research is clearly defined. The limitations of the problem in this study include the emphasis on "accountability" which refers to the dimension of accountability according to the Bovens Model, and then the object of research used is the Information and Complaints UPIK Handling Unit of the Regional Government of Yogyakarta and Qlue Jakarta owned by the DKI Jakarta Regional Government. Determined the period of UPIK comparative analysis with Qlue referred to in this study is 2014-2017 period so that it helps researchers process the necessary data relating to the two objects, including the list of informants, and supporting documents.

Data collection was carried out by in depth interviews for 3 months from October to November 2018 as well as additional supporting data for the visual material method. There were research subjects for the main informant and additional informants. The main informants are implementers of digital based public complaint service policies, namely employees and administrators of DKI Jakarta Communication, Information and Statistics Office, as well as the Yogyakarta City Office of Relations, Communications and Information, and selected communities of UPIK and Qlue users are additional informants. Testing the validity of the results of the study was carried out by means of data triangulation.

\section{Results \\ Digital Based Public Complaint Service Innovation (Qlue \& UPIK)}

Entering the digital age of the industrial revolution 4.0, based on the results of a survey of the Association of Indonesian Internet Service Providers (APJII, 2017), mentioning that the high growth of the Internet in Indonesia is partly due to the large use of the internet for lifestyle needs. In addition, $87.13 \%$ of 
internet users use it for social media purposes. While the percentage for Indonesians is still low in accessing public information such as administration, regulations or laws, services and complaints, which is no more than an average of $15 \%$. This figure is a challenge for the government in conducting technology based innovations. The Indonesian government is required to optimize public service innovations in order to increase accountability and professionalism. At the regional level, there are many public complaints services that are managed by digital based local governments such as in Yogyakarta (UPIK) and Qlue in Jakarta. However, given the low percentage of internet usage in the field of public services in addition to the effectiveness being highlighted, accountability for service providers is also an important question. To realize the use of the internet as a media for connecting complaints and public complaints, innovation is needed, supported by McLuhan (2003) in Understanding the Media: The Extensions of Man, it is stated that:

"This fact merely underlines the point that "the medium is the message" because it is the medium that shapes and controls the scale and form of human association and action. The content or uses of such media are as diverse as they are ineffectual in shaping the form of human association. Indeed, it is only too typical that the "content" of any medium blinds us to the character of the medium"

If integrated in the context of this paper, Qlue and UPIK, which is public technology based public complaint services and social media as a medium influence and encourage activities in the public audience. Digital based media with the specificity it carries is also explained by Chan, Cho \& Lee (2013, p. 152), both media in the form of web or social media in definitions that are more effective and easy to understand, are online platforms to interact, collaborate and create or share various kinds of digital content.

According to the acknowledgment from the informant who was a Qlue user, most of them claimed to know Qlue information from various media or informants. Nearly half of the speakers claimed to know Qlue from other social media that were more popular, such as Youtube, Facebook, and Twitter. The rest are from television, from relatives who have used Qlue and socialization from RT. As quoted by one user, according to their acknowledgment, direct socialization from the government was lacking because information about Qlue was partly on the internet or even news on television. Based on a statement from the user, they admitted that they rarely access the JSC portal (Jakarta Smart City) via the web. Almost all of the speakers admitted that they rarely open websites; some claim that they have never opened a JSC website at all. This is certainly different from UPIK service users, where the website is the main point of access to the use of digital public complaints services in Yogyakarta City. The main purpose of using the website is to convey the main information and directly from the government to the community. The logic of reporting applications requires a good level of rationality from the community, in an effort to produce credible input. One form of the initial effort taken by the government first was to build an information system in the form of a portal. After that, the government must also see whether the portal is accessed by the community or not. Because this is related to the issue development process or sensitivity in seeing issues that become public problems.

The Qlue application is a digital application that was integrated with the DKI Jakarta Provincial Government (DKI Jakarta Provincial Government) in a smart city program that had been carried out since 2014 ago. This application appears in the form of social media that invites public participation 
to report complaints and care about the surrounding environment. With the Qlue social media application, Jakarta residents can report complaints about environmental conditions such as garbage, floods, congestion, road damage, fires, and others. In addition, progress reports can be monitored to ensure that all complaints submitted are followed up. The Qlue social media application that has a concept "a smart city solution" is not an application belonging to the DKI Jakarta Provincial Government in person, but it is under PT Terralogiq, which has now changed its name to PT Qlue Performa Indonesia. Qlue's social media application also not only cooperates with DKI Jakarta, but also several other cities in Indonesia such as Pekanbaru, Manado, Bima city, and Probolinggo city. DKI Jakarta Provincial Government has collaborated with the Indonesian Performance Committee for ten years to support the DKI Jakarta smart city program.

Different from UPIK, which has information that was initiated by the Mayor of Yogyakarta (Herry Zudianto) that the formation of UPIK emerged in 2003 which launched and socialize of the use of UPIK began on February 29,2004 . The formation of UPIK was based on existing problems, including: 1) Not all citizens know the channel of complaints that can be used easily, 2) There are obstacles when meeting people with officials or authorities, and 3) There are fear and reluctance to complain about complaints among the community. UPIK that has been running so far shows a number of very significant changes. In its journey, UPIK services initiated by the Yogyakarta City Government received good responses from the community with the many complaints, questions, information, and suggestions that were conveyed through SMS, telephone, website and channels that were opened by the Yogyakarta City Government in this UPIK service.

\section{Complaint Handling Management by Qlue and UPIK}

Aboutits management, Qlue media is only an intermediary and supervisory application that makes it easier for people to interact with the local government. The community reports included in the Qlue will be integrated into the portal www.smartcity.jakarta.go.id and later will be integrated by the Jakarta Smart City (JSC) into the application of the Rapid Public Opinion Response (CROP). All public reports through the Qlue application are directly connected to the CROP application owned by the DKI Jakarta Provincial Government apparatus. Qlue is an application intended for the community, while CROP is an application that can only be downloaded by DKI Jakarta Provincial Government officials and police officers for TL (Follow Up) reports of the community in Qlue. Reports from the public that were mapped digitally and integrated in official website smartcity.jakarta.go.id. All public reports, which have entered Qlue, must be follow up by the authorities and related OPD (Regional Device Organization) through the CROP application.

Furthermore, related to the problem of managing messages delivered through the UPIK website, the inclusion of complaints that can be resolved at the UPIK operator level will immediately receive a response. However, if the complaint needs to be coordinated with the agency, a meeting will be held under the coordination of the Regional Secretary then forwarded to the Head the Office of the Regional Information Agency. It is conducted in order to provide an answer; if the complaints of citizens are related to irregularities in the administration of the government, then it is immediately submitted to the Mayor for steps to be resolved. In terms of time, messages that are relatively simple and can be followed up by an OPD or agency are attempted to get feedback within a maximum of $2 \times 24$ hours on weekdays, while messages that require 
further coordination on cross agency or OPD to provide feedback are promised at the longest $6 \times 24$ hours.

\section{Discussion}

The formation of digital public service innovations as the beginning of the government's commitment to fight against KKN (Collusion, Corruption, and Nepotism) was realized by UPIK, also to facilitate communication links between the government and the community. Access to community participation is opened not only to accommodate community complaints, in complaints handling management UPIK also responsible for conveying information and complaints to each department or work unit. Moreover, it provides information related to responses or follows up complaints and input. Whereas Qlue is one application that was integrated with Jakarta Smart City for reporting complaints and appreciation of the surrounding environment in real time in Jakarta with the aim of providing an idealistic solution for Jakarta. Therefore, it is very interesting to find out how UPIK and Qlue's strategies are in building the principle of public accountability.

The importance of public accountability in a scientific perspective is noted by Bovens's dialectic $(2015$, p. 230) that the role of the concept of public accountability is important to provide true democratic meaning, in order to monitor and control government behavior and actions. Then, accountability should be able to help prevent violations that occurred at the executive level. Then Aucoin and Heintzman (2000) in Bovens, (2015, p. 230) stated that accountability should increase capacity and effectiveness at the executive level as well as partnerships in government. Different perspectives on the rational for public accountability can lead to different judgments for each practice of accountability.

The framework used in this study adapts an accountability concept of Bovens, Schillemans and Hart's (2015) which focus on the four main functions of accountability. (1) Democratic control is an accountability to control and legitimize government actions by linking them to a chain of democratic delegations; (2) Guarantee is an accountability to protect the tendency of concentration of power and abuse of power in the executive branch; (3) Learning is an accountability that provides interrelated relationships between public officials and public agents (community) in order to improve efficiency and effectiveness; (4) Performance is an accountability that focuses on ensuring that the public resources used meet the expected public policy targets.

These four main functions are relevant to the conditions of public sector accountability that provide democratic control (the role of democracy) broader guarantees including loyalty to rules and regulations (constitutional roles), norms and values related to administration to prevent corruption and abuse of power. As well as increasing efficiency and effectiveness (the role of learning) and the role of 'results' added to capture trends in accountability, reform that focus on 'results' or performance-based accountability (Jarvis, 2015). The four objectives of accountability will identify the implementation of public services in the form of UPIK and Qlue digital public complaints services, so that they will answer the question of whether UPIK and Qlue are able to promote accountability or not.

\section{Development of Public Complaint Accountability Services as a Democratic Role}

The main function of accountability of democratic roles according to the Bovens model seeks to support the role of domestic actors from various political spectrums in assessing the extent to which citizens can hold governments accountable for delivering services that they received, through democratic means. The idea of democratic accountability includes either direct or indirect, vertical, horizontal or diagonal political or social accountability or 
other mechanisms that underlie democratic principles that prioritize community control over public decision-making (Bovens, 2007). Democratic accountability requires the ability of citizens countries in voicing their demands so that they can influence the decision making process through public complaints service facilities.

Accountability in public services especially in the city of Yogyakarta is considered good in the provision of information and in receiving citizen complaints for public services provided by government officials, based on the Community Satisfaction Index (IKM) produced according to the CPPS UGM study (2014) that UPIK media succeeded in providing performance high community satisfaction. Although the performance of the Public Relations and Information section has been quite good from year to year according to the measurement of IKM, but it then not makes the Public Relations and Information department proud of themselves, there are still many challenges faced to improve the performance of the Public Relations and Information section, especially UPIK.

In terms of accountability, the willingness of employees to help the community if one day the community experiences difficult in accessing public services. Responsiveness in processing complaints by government employees can also be detected through the Qlue social media application, then Governor of DKI Jakarta and our community can monitor the performance of government employees. This certainly will make it easier for the public to monitor the response from the government. Make easier for the Governor of DKI Jakarta to appreciate all achievements by employees through Qlue. Means that government officials in carrying out services have been responsible to the community. Accountability is not an exclusive concept that only exists in democracy, but when accountability is democratic, it has the potential to improve government performance. Therefore, the term democratic accountability is used in guidelines to explain an idea that more comprehensive, broad, and integral, not a concept that is limited, narrow, and exclusive.

\section{The Role of Guarantees Realized by Digital Public Complaint Service Accountability}

Accountability analysis from the guarantee perspective of the Bovens model (2015) has become very important to resist the tendency of concentration of power and abuse of power at the executive level. Once in five years the regional leadership, especially the city of Yogyakarta and the DKI Jakarta Province experienced a change. Whether during the leadership period which has changed, the use of public complaints services will have trouble or not. This is considering that changing leadership styles and policies may have different impact on the role of Qlue and UPIK as media for handling complaints.

Contestation and Debate in Decisional Role (Role of Decision Makers)

Based on the findings of this study, various aspects have become weaknesses and barriers of UPIK and Qlue. In UPIK service, some of these are still limited authority over coordination between UPIK work units and Regional Work Units (SKPD), which are now reported as OPD (Regional Device Organizations). Technical barriers such as hardware and software in each OPD, and not all complaints can be resolved within $2 \times 24$ hours, even though the UPIK service is 24 hours but the officers and other OPD are only limited according to office hours.

Whereas in Qlue's services, complaints from residents via Qlue regarding Jakarta's public problems declined in the era of Anies-Sandiaga leadership, and the average settlement was getting longer. This was different in the previous leadership period. Qlue is considered synonymous with Ahok, 
which collaborates with this application in the management of Jakarta Smart City. Ahok even required the neighborhood / hamlet to report activities via Qlue, but then it is deleted because they triggered polemic. Since Anies and Sandiaga Uno occupied the Jakarta City Hall in October 2018, and they announced the seventh complaint online channel. In addition, the complaints can be posted each village. The patterns and management of citizen reporting have been changed, no longer centralized (decentralization) in a Qlue complaint application service. Then the trend of complaints via Qlue decreased, based on Jakarta Smart City data, in December 2016 there were 28,901 and then the declining reports occurred in the Anies Bawesdan era and in December 2017 there were only 10,759 reports. In addition to declining reports, the slow follow up of services in a number of complaints was caused by the government requiring a large budget and the reporting area within the authority of the central government.

The role of the decision maker is related to leadership commitment. There is a risk of involvement and dependence of leaders in decision makers, so that the Head of Regional Government must be prepared to be responsible if the decision will pose a threat to the organization that had supported. In the Qlue service led by the Head of Information and Statistics and UPIK Communication Services by the Head of the Yogyakarta City Office of Relations Communication and Information, he understands that the responsibility for organizing digital-based public complaints services is in his hands, the responsibility for resolving public complaints. Leadership guarantees management and management of services for public satisfaction. In addition to the decisions in his government, the leadership of the organization must also be able to negotiate with other parties outside the organization, including OPD (Regional Organization Devices) involved in resolving input of public complaints in certain fields. Based on the results of the interviews conducted, the understanding of the leadership's responsibility in carrying out the implementation of public complaints services was able to decide and put forward the proportionality of resolving public complaints issues.

The obstacle in the process is the Qlue service, where Qlue services according to its development based on the change of leadership of the provincial leadership, which of course has higher level of leadership than the manager of public complaint service management, experiencing a downward trend in the existence of Qlue in DKI Jakarta society. This is a debate and contestation in the Qlue program's accountability function related to its relevance to the Bovens theory model (2015) that accountability in terms of guarantee functions to evaluate credibly, especially regarding the suitability of actions with laws, regulations, and norms. However, during the contestation of the decision role (Robin and Judge, p. 2008) does not violate organizational rules, the guarantee function of organizational accountability is still realized. This happens to UPIK services. Where in terms of commitment, from the side of the UPIK work unit, it has demonstrated its commitment to provide efficient, fair, and timely handling of complaints while maintaining UPIK as a media for handling complaints in each Mayor's leadership period.

\section{The Accountability Function as a Learning Role Provides a Relationship to the Efficiency and Effectiveness of the Implementation of Digital Public Complaint Services}

Accountability according to the Bovens model (2015) provides interrelated relationships between public officials and public agents in order to increase efficiency and effectiveness. Related to the interaction of using Qlue and UPIK, there are a number of things that can be seen, namely through the intensity of the use 
of Qlue and UPIK, reporting problems, and interactions in discussions both in the regional discussion room and in the comments column seen from the intensity. In terms of the intensity of Qlue usage, the average is related to the interest to report. Qlue users will usually open the application if indeed they find a problem and feel the need to report. Those who already have Qlue on an average smartphone choose to report using Qlue instead of using other public complaints service media, or reporting directly to the nearest apparatus. This also happens to active users of UPIK services, especially the people of Yogyakarta City who are sufficiently aware and critical to convey their complaints to UPIK media. Apart from being not too time consuming, more effective, and tends to be easy to use, some users claim to have experience with reporting directly to the authorities cannot be directly dealt with but require a time process.

In addition to the assessment of accountability function as a role for learning from public perspective as a user, then the use of the primary characteristics of organizational culture from Robbins and Judge (2008). Its relevance to the Bovens model, which states the function of accountability, is the role of accountability in terms of efficiency and effectiveness in the provision of complaint services. It is seen from the approach of the organizing organization in taking responsibility for financial use. Robbins and Judge (2008) efficiency and effectiveness are realized by public accountability for attention to the details and orientation of financial statements, both income reports and expense reports. In addition, in UPIK services and Qlue, it was known that the financial organization was good and there was no evidence of bribery and fraud by officials. Then the employees both have the freedom to increase their capacity, whether they participate in training from the Job Training Center or other training. In matters that are not principals, employees may decide something. The things that are not principals here mean such activities as outside decisions in ratifying laws or other regulations.

Based on these characteristics, it can be seen that the organizational culture built by UPIK and Qlue almost fulfills the aspects of good governance. It has also been mentioned above, that the accountability function approach as a role for learning that is able to provide efficiency and effectiveness can provide organization promotion that is accountable. The organizational culture that is proven in this study does not prevent the organization from implementing program management accountability.

\section{Media Accountability Roles in Results/ Performance}

The interesting thing about the shift in urban society especially dominating Java in the description of increasing internet penetration is in line with what Sztompka (2011, p. 27) states that society should not be imagined as a fixed state, but as a process, not a false object which is rigid but as a flow of events continuous. It is recognized that society can only be said to exist so far and as long as something happens in it such as action, even changes such as the use of technology have mainly provided clear differences in how information is now consumed and distributed by the same audience. Humans will not be able to live without technology. Humans and technology itself has a symbiotic relationship, meaning that technology is something that is created by humans themselves, and as a result, technology that has been created by humans will recreate the human self that uses these technologies (West \& Turner, 2008, p. 138). Based on these assumptions that want to be emphasized in this paper is how the use of new media based on social media such as Qlue and UPIK on the dynamics of the results and performance of the organizers.

In terms of performance improvements where settlement must refer to performance improvements, UPIK has always taken 
measures to measure community satisfaction aimed at identifying community satisfaction and improving performance continuously. From all these things, only one thing has been that UPIK has not yet provided sufficient and timely responsiveness. This is because it is constrained by the limited number of human resources and the level of workload owned by the operator and admin UPIK is still excessive and has dual jobs so the message cannot always be delivered quickly.

The realization of accountability is also related to the level of understanding of Qlue and UPIK users on their function or performance, as well as the level of knowledge of environmental problems that need to be reported. In addition, how are the government's efforts to encourage the community to be more participatory and actively use digital public complaints service media. This is relevant with the hope of the initial establishment of Qlue, the DKI Jakarta Government is targeting that prospective Qlue users are active users or at least those who already have access to use digital communication devices. The government is trying to optimize social media users by providing information on the Qlue application. Aside from utilizing existing resources, this action is also considered more effective and efficient. More about the socialization of Qlue from JSC together with the socialization of the Jakarta Smart City program itself. As for Qlue's special socialization, Qlue developers did more. According to the explanation from the developer, it took about one year to socialize the use of Qlue. The fact that the effectiveness of the OPD and other agencies involved and tasked with completing the report from Qlue is supported by government intervention by providing incentives that are not small to DKI Apparatus, including employees managing Qlue. The amount of salary for apparatus, which has fantastic, includes basic salary, office allowance, static TKD (employee attendance), dynamic TKD (performance allowance), and transportation allowances for structural officials such as village heads who are involved in solving Qlue report problems. This fantastic amount of income was able to trigger all government parties to obey and be actively involved in implementing policies, including Qlue. Commitment to utilizing technology today is not only a massive case of using technology, but also the support of incentives providing incentives to promote accountability that results in good performance.

\section{Conclusion}

After seeing the various dimensions of the accountability approach from the Bovens (2007) model that influence the implementation of Qlue and UPIK processes, a correlation of the four functions of accountability has been carried out which includes the functions of democratic control, assurance, learning and performance towards both the organizer and user approaches. All the results of the field findings show that the level of the dimensions of accountability is almost fulfilled. Factors that encourage accountability are democratic control of public oversight, as well as guarantees of organizational culture, while factors that hinder accountability are the commitment of leaders.

The results of the study indicate that the four functions have a relationship to the implementation process of Qlue and UPIK. The functions of democratic control, guarantees, learning, and performance have a strong relationship with the implementation of the implementation of digital based public complaints services. The accountability function is particularly in the role of UPIK's performance in the last four years even though there has been a change of leaders, the performance of this institution still performs well and meets public expectations in providing public services, in contrast to Qlue services which are intervened with leadership changes. The accountability function embedded by Qlue 
is being able to cut bureaucrats efficiently, in addition to the political system, commitment to leadership and dynamic user existence. Where the quality of UPIK systems is still below Qlue, but for accountability capacity UPIK is more consistent in meeting key elements to promote accountability through effective complaints handling mechanisms. It's not only a matter of more modern means that will achieve effective results, because the performance of a program that supported by the appropriate model and complaint handling mechanism able to promote an accountable organization.

\section{References}

Asosiasi Penyelenggara Jasa Internet Indonesia [APJII]. (2017). Penetrasi \& perilaku pengguna internet indonesia profil pengguna internet Indonesia. Jakarta: Asosiasi Penyelenggara Jasa Internet Indonesia. Retrieved November 23, 2018, from https://www.apjii.or.id.

Aucoin, P., \& Heintzman, R. (2000). The dialectics of accountability for performance in public management reform. International Review of Administrative Sciences, 66, 45-55.

Bovens, M., Schillemans, T., \& Hart, P. (2015). Does public accountability work? An assessment tool. Public Administration Blackwell Publishing, 86(1), 225-242.

Bovens, M. (2007). Analysing and assessing accountability: A conceptual framework. European Law Journal, 13(4), 447-468.

Chan, S. M., Cho, M., \& Lee, S. (2013). User perceptions of social media: A comparative study of perceived characteristics. Journal of Communication and Media Technologies, 3(4), 149-178.

Cohen, S., Rossi, F. M., Caperchione, E., \& Brusca, I. (2018). Local government administration systems and local government accounting information needs: Is there a mismatch?. International Review of Administrative Sciences. doi: 1177/0020852317748732
CPPSUGM. (2014). Hasil pengukuran IKM pada pelayanan UPIK 2014. Retrieved November 23, 2018, from https://cpps. ugm.ac.id/wp-content/uploads/2016/09/ RINGKASAN-EKSEKUTIF-HasilPengukuran-IKM-Pelayanan-UPIK-2014. pdf

Creswell, J. W. (2010). Research design: Pendekatan kualitatif, kuantitatif, dan mixed. Yogyakarta: PT Pustaka Pelajar.

Denhardt, J. V., \& Denhardt, R. B. (2007). The new public service: Serving, not steering. New York: M.E Sharpe, Armonk.

Ghilad, S. (2008). Accountability or expectations management? The role of the ombudsman in financial Regulation. Baldy Center for Law and Social Policy, 30(20), 228-253.

Hammami, S. M. (2011). Exploring the information technology contribution to service recovery performance through knowledge management system. The Journal of Information and Knowledge Management Systems, 41(3), 296-314.

Irvine, C., Robertson, R., \& Clark, B. (2010). Alternative mechanisms for resolving disputes: A literature review (Rep.). UK: University of Strathclyde.

Jarvis, M. (2015). The black box of bureaucracy: Interrogating accountability in the public service. Australian Journal of Public Administration, 73(4), 450-466.

McLuhan, M. (2003). Understanding media: The extension of man. London \& NewYork: Gingko Press.

Ombudsman Western Australia. (2017). Guidelines: effective handling of complaints made to your organisation-An overview. Retrieved September 22, 2018, from http://www.ombudsman.wa.gov. au/Publications/Documents/guidelines/ Effective-handling-of-complaints-madeto-your-organisation.pdf.

Osborne, \& Gaebler, T. (1993). Reinventing government: How the entrepreneur spirit is 
transforming the public service (A. Rosyid \& Ramelan, Trans.). Jakarta: Pustaka Binaman Pressindo.

Osborne, S. (2010). The new public governance? Emerging perspective on the theory and practice of public governance. New York: Routledge

Peters, B. G. (2010). The politics of bureaucracy: An introduction to comparative public administration, 6th edition. New York: Routledge.

Portal Resmi Pemerintah Kota Yogyakarta [Web log post]. (2019, January 1). Retrieved from https://jogjakota.go.id.

Portal Resmi Pemerintah Provinsi DKI Jakarta [Web log post]. (2019, January 1). Retrieved from https://jakarta.go.id/

Portal Jakarta Smart City [Web log post]. (2019, January 1). Retrieved from www. smartcity.jakarta.go.id.

Pramusinto, A. (2013). Building complaint handling mechanisms for effective leadership. International Journal of Administrative Science and Organization, 2(3), 144-152.

Robbins, S. P., \& Judge. (2008). Organizational Behavior (Second Edition). Jakarta: Salemba.

Ross, H. L, \& Littlefeld, N. O. (2013). Complaint as a problem-solving mechanism. Law $\mathcal{E}$ Society Review, 12(2), 202.

Rotchanakitumnuai, S. (2013). The governance evidence of e-government procurement. Transforming government: People, Process and Policy, 7(3), 309-321.
Starling, G. (2008). Managing the public sector 8th edition. Boston, M. A.: Thompson Wadsworth.

Sururi. (2017). Inovasi kebijakan dalam perspektif administrasi publik menuju terwujudnya good public policy governance. Spirit Publik, 12(2), 14-31.

Sztompka, P. (2011). Sosiologi perubahan sosial. Jakarta: Prenada Media. 27.

Qlue [Web log post]. (2019, January 1). Retrieved from http://www.qlue.co.id/.

Unit Pelayanan Informasi dan Keluhan (UPIK) Pemerintah Kota Yogyakarta [Web log post]. (2019, January 1). Retrieved from http://upik.jogjakota.go.id.

West, R., \& Turner, L. H. (2008). Pengantar teori komunikasi, analisis dan aplikasi (Third Edition). Jakarta: Salemba Humanika.

Wong, W., \& Welch, E. (2004). Does e-government promote accountability? A comparative analysis of website openness and government accountability. An International Journal of Policy, Administration, and Institutions, 17(2), 275-297.

Yang, K. (2012). Further understansing accountability in public organizations: Actionable knowledge and the structure-agency duality. Administration and Society, 44(3), 255-284. doi: 10.1177/00953999711417699

Yohanitas, A. W. (2016). Creating good governance through innovation in public service at Surakarta Municipality. Jurnal Borneo Administrasi, 12(3), 239-257. 


\section{APPENDIX}

\begin{tabular}{|c|c|c|c|}
\hline \multirow{2}{*}{$\begin{array}{l}\text { Analysis } \\
\text { Aspects }\end{array}$} & \multicolumn{2}{|c|}{ Digital Public Complaint Service } & \multirow{2}{*}{$\begin{array}{c}\text { Analysis } \\
\text { Description }\end{array}$} \\
\hline & UPIK & Qlue & \\
\hline \multirow[t]{2}{*}{$\begin{array}{l}\text { a. Quality } \\
\text { System }\end{array}$} & $\begin{array}{l}\text { - Infrastructure } \\
\text { guaranteed, web handled } \\
\text { by Dishubkominfo } \\
\text { Yogyakarta city } \\
\text { - Mentioned in certain } \\
\text { Perda / Pergub } \\
\text { - Shared commitment OPD } \\
\text { leaders based on loyalty } \\
\text { on the organization } \\
\text { - There is a network that } \\
\text { is formed in a chart } \\
\text { from tasks and functions } \\
\text { organization Government } \\
\text { City of Yogyakarta }\end{array}$ & $\begin{array}{l}\text { - Infrastructure guaranteed, } \\
\text { application parent social media } \\
\text { handled professionally by } \\
\text { PT.Qlue Informa with the Office } \\
\text { Relationship Communication and } \\
\text { DKI Jakarta Statistics } \\
\text { - Mentioned in certain Perda / } \\
\text { Pergub } \\
\text { - Shared commitment OPD } \\
\text { leaders based on loyalty on the } \\
\text { organization } \\
\text { - There is a network that is } \\
\text { formed in a chart from tasks and } \\
\text { functions organization Provincial } \\
\text { government DKI Jakarta }\end{array}$ & $\begin{array}{l}\text { There are differences } \\
\text { seen in the suggestions, } \\
\text { infrastructure, and } \\
\text { policies that underlie } \\
\text { the implementation } \\
\text { of digital public } \\
\text { complaints services. } \\
\text { While the equality of } \\
\text { conditions in terms } \\
\text { of commitment and } \\
\text { networking is formed. }\end{array}$ \\
\hline & Very Good & Good & \\
\hline \multirow[t]{2}{*}{$\begin{array}{l}\text { b. Information } \\
\text { Quality }\end{array}$} & $\begin{array}{l}\text { - There are signs of } \\
\text { bureaucrat ethics } \\
\text { to maintain value } \\
\text { information. } \\
\text { - Information is naturally } \\
\text { normative, enough } \\
\text { benefits influence society. }\end{array}$ & $\begin{array}{l}\text { - Not paying too much attention } \\
\text { to the report's ethical signs, in } \\
\text { order to maintain the value of } \\
\text { transparency } \\
\text { - Information is technically } \\
\text { operational; the benefits have } \\
\text { enough impact on the community. }\end{array}$ & $\begin{array}{l}\text { The quality of } \\
\text { information produced is } \\
\text { influenced by the value, } \\
\text { benefits, and relevance } \\
\text { of the answer to the } \\
\text { problem. }\end{array}$ \\
\hline & Good & Very Good & \\
\hline \multirow[t]{2}{*}{$\begin{array}{l}\text { c. Service } \\
\text { Quality }\end{array}$} & $\begin{array}{l}\text { - System response is } \\
\text { sufficient, reports } \\
\text { undergo a process of } \\
\text { moderation before airing, } \\
\text { while the response } \\
\text { content depends on the } \\
\text { responsiveness of each } \\
\text { OPD in understanding } \\
\text { the problem }\end{array}$ & $\begin{array}{l}\text { - Good system response, indicated } \\
\text { by reports that immediately } \\
\text { aired, while the response content } \\
\text { was entirely dependent on the } \\
\text { Governor }\end{array}$ & $\begin{array}{l}\text { Digital public } \\
\text { complaints service as an } \\
\text { information system does } \\
\text { not involve HR services } \\
\text { to interact directly with } \\
\text { users, service quality } \\
\text { is reflected in response } \\
\text { content as information } \\
\text { output }\end{array}$ \\
\hline & Good & Good & \\
\hline \multirow[t]{2}{*}{$\begin{array}{l}\text { 2. Public } \\
\text { Participation }\end{array}$} & $\begin{array}{l}\text { - The intensity of usage } \\
\text { tends to increase, } \\
\text { reflecting the growing } \\
\text { interest of the community }\end{array}$ & $\begin{array}{l}\text { - The intensity of usage tends to } \\
\text { decrease, showing reduced public } \\
\text { interest }\end{array}$ & $\begin{array}{l}\text { The existence of using } \\
\text { and interest still indicate } \\
\text { that the mass media } \\
\text { can rely on this digital } \\
\text { public complaint as a } \\
\text { communication service }\end{array}$ \\
\hline & Very Good & Good & \\
\hline \multirow[t]{2}{*}{$\begin{array}{l}\text { 3. Service } \\
\text { Benefits } \\
\text { for the } \\
\text { Operator }\end{array}$} & $\begin{array}{l}\text { Direct Benefits } \\
\text { - Being a means of public } \\
\text { participation, as well as } \\
\text { a database for material } \\
\text { development policy and } \\
\text { planning } \\
\text { Indirect Benefits } \\
\text { - Improve cross sector } \\
\text { coordination }\end{array}$ & $\begin{array}{l}\text { Direct Benefits } \\
\text { - Become a space for community } \\
\text { and government dialogue, as well } \\
\text { as a means of public participation } \\
\text { Indirect Benefits } \\
\text { - Improve the positive image of the } \\
\text { organizer }\end{array}$ & $\begin{array}{l}\text { The main benefits } \\
\text { related to the function } \\
\text { and role of digital public } \\
\text { complaints services are } \\
\text { well fulfilled. }\end{array}$ \\
\hline & Very Good & Very Good & \\
\hline
\end{tabular}

Source: Private Data 